\title{
肝細胞癌の肝内進展様式と切除後残肝再発との関連性に関する研究
}

\author{
東京女子医科大学消化器病センター－（主任：羽生富士夫教授）
}

山本雅 一

\section{A STUDY OF THE RECURRENCE IN THE REMNANT LIVER OF HEPATOCELLULAR CARCINOMA IN RELATION TO THE MODE OF IT'S GROWTH}

\section{Masakazu YAMAMOTO}

Institute of Gastroenterology, Tokyo Women's Medical College

82例の肝細胞癌切除例の切除標本について肝細胞癌の肝内進展様式を検索し, 残肝再発との関連性 について検討した，再発は52例に認め，そのうち51例が残肝再発であった．再発の時期は42例が術後 2 年以内であった。 2 年以内に残肝に再発した症例は非再発例と比較し有意に生存率が低かった $(\mathrm{p}<$ 0.001). 2 年以内残肝再発之有意な関連を認める肝内進展様式は被膜浸潤, 肝内転移であり, 門脈侵 襲の有無では有意差を認めなかった。これら3つの肝内進展様式は相互に有意な関連があり，これら をまとめて肝細胞癌の肝内進展因子とすると，この因子の有無にて残肝再発に有意差を認めた（ $\mathrm{p}<$ 0.01 ).

卖引用語：肝細胞癌に対する肝切除術, 肝細胞癌残肝再発, 肝細胞癌肝内進展様式

\section{緒言}

近年の肝癌に対する画像診断の進歩は単に早期発見 への寄与ばかりではなく癌病巣の病態診断についても 多くの情報をもたらしている。この結果切除術式に関 してもより明確な判断が可能となってきている。しか しながら，治癒切除であるにもかかわらず，肝切除後 の残肝に再び肝細胞癌が出現することを多く経験する に至った，肝細胞癌切除例の予後を左右するのは残存 肝内の再発であり，これらに対する対処の重要性が認 識されてきている。 そこで，肝細胞癌切除例から肝内 進展様式を検討し，残肝再発との関連性につき検討し た。

\section{対象および方法}

昭和 54 年から 60 年 12 月までに東京女子医科大学消化 器病センターにて肝切除を施行した肝細胞癌は176例 である。このらち絶対非治瘾切除25例, 術後 2 年以内 肝不全死28例, 術前肝動脈塞栓術 (transcatheter arterial embolization, 以下 TAE) 21例, 再切除 7 例, 術 後経過不明13例を除いた82例の肝細胞癌切除例を対象 とした，摘出された標本は速やかに割を加え，その最

$<1988$ 年10月 12 日受理 $>$ 別刷請求先 : 山本 雅一 干162 新宿区河田町 8-1 東京女子医科大学消化 器病センター

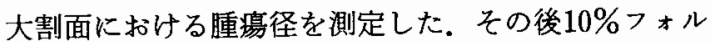
マリン液で十分に固定したのち, 約 $0.5 \sim 1.0 \mathrm{~cm}$ の厚 さにスライスしこの1スライスに5〜10個のパラ フィン切片を作製した。染色は Hematoxylin-Eosin 染 色，Azan-Mallory 染色，鍍銀染色を行った。

再発は肝切除により一度臨床的に消失した肝細胞癌 が再び出現することとした。再発の確認は病理組織学 的検查 (細胞診, 再切除後組織診, 剖検など), または computed tomography, 血管造影, 超音波検查のいず れか 2 つ以上で確診しているものとした。再発の時期 は病理組織学的検查, 画像診断にて再発が確認される 以前に，再発の所見が客観的に初めて明らかになった ときとした。

最終確認日は昭和62年12月31日とし, 手術後の観察 期間は最長 8 年 10 か,, 最短 9 か月であったが, 非再 発例は最低術後 2 年の経過観察をした。

術前 HBs 抗原, 術前 $\alpha$-Fetoprotein(以下 AFP) 值, 腫瘍径, 肉眼所見, 肝硬変の有無, 原発性肝癌取扱い 規約 (1987年 7 月 $)^{11}$ と従った切除根治度, 肝切除範囲, 肝切離面に拈ける癌浸潤の有無の判定（以下 TW 因 子), 肉眼的進行の程度の分類 (以下 Stage), 肝内進展 様式(被膜浸潤(fc-inf), 門脈漫襲(vp), 肝内転移(im)) と残肝再発との関係について検討した。な技肝硬変に 
ついては三宅の分類を使用し，三宅の乙型に相当する ものは肝硬変群に入れ, 中等度の線維症は非硬変群と した。高た，肝内転移病巣と多中心性発癌病栄との鑑 別が不能のため主腫瘍以外の腫瘍は肝内転移とした。 肉眼分類は腫瘍周囲の進展様式を考慮した高崎の臨床 病態分類 ${ }^{2}$ を使用した。この分類では, 主腫汮の周囲肝 組織への癌進展様式により, 結節型腫瘍を限局結節型 (周囲へ癌増殖を認めない), 結節増殖型（周囲に連続 した癌堌殖を伴うが肝内転移は認めない), 結節進展型 (周囲に肝内転移を認める), 塊状型腫境を限局塊状型 (周囲に肝内転移を認めない), 塊状進展型（周囲に肝 内転移を認める）と分けた。なお，結節型，塊状型の 定義は原発性肝癌取扱い規約 ${ }^{1} に$ 準じている。

有意差検定には $\chi^{2}$ 検定を使用した。生存率の計算は Kaplan-Meier 法, その有意差検定には一般化 Wilcoxon 検定を使用した。 また，判別に関する分析とし て数量化第II類を用いた。

\section{1) 対象 82 例の概要}

年路は30〜77歳, 平均58歳. 男女比は65：17. 82例 の5ち肝硬変は 58 例 $(71 \%)$, 原発性肝癌取扱い規約に おける肉眼的進行度の分類ではStage I 17例, II 39 例, III 24例，IV 2 例であった。 また，手術は亜区域切 除に至らない切除 (Hr0) 24例, 严区域切除 (HrS) 32 例， 1 区域切除 ( Hrl) 12例， 2 区域以上の切除 ( $\mathrm{Hr} 2$ 以上）14例，木た原発性肝癌取扱規約による絶対治瘜 切除 9 例, 相対治癒切除 49 例, 相対非治癒切除は 24 例 であった。

\section{2) 再発の概要}

対象82例のうち52例（63\%）に再発を認めそのうち 51例は残肝再発であった。 その他の再発臓器として, 肺転移再発 8 例, リン八節転移再発 2 例, 腹壁転移再 発 1 例を認めた。腹壁転移再発の 1 例を除き, 他臓器 再発の症例は全例残肝再発を併存していた（表 1 ）。

3) 残肝再発の時期

残肝再発51例の再発の時期は，術後 3 か月から 4 年 10か月と長期にわたるが，うち42例（82\%）が術後 2 年以内であった（図 1 ).

4) 術後 2 年以内残肝再発例と非再発例の生存率

術後 2 年以内残肝再発例の 3 年生存率は $46 \%, 5$ 年 生存率は $19 \%$ と非再発例と比較し有意に $(\mathrm{p}<0.001)$ 低かった（図 2 ).

5) 術後 2 年以内残肝再発之諸因子の検討 術後 2 年以内残肝再発と $\chi^{2}$ 検定にて有意の相関を
表 1 肝細胞癌の再発数と再発部位

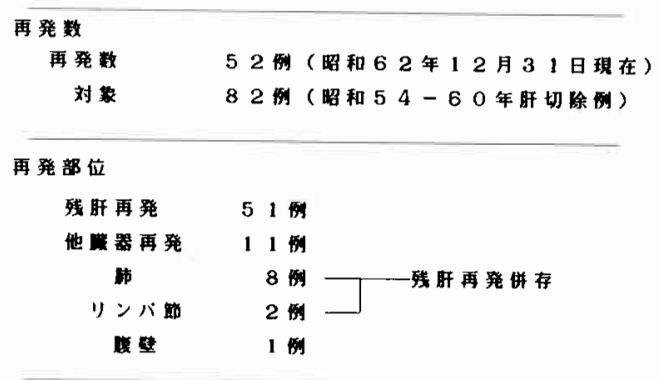

図 1 肝細胞癌切除後の残肝再発時期の分布

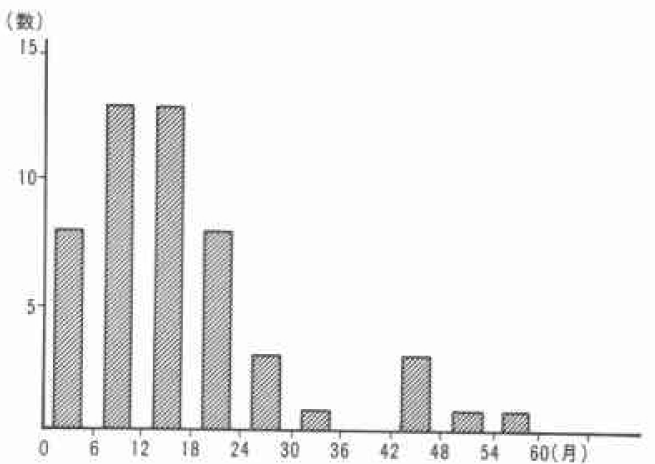

図 22 年以内残肝再発, 非再発例の生存曲線

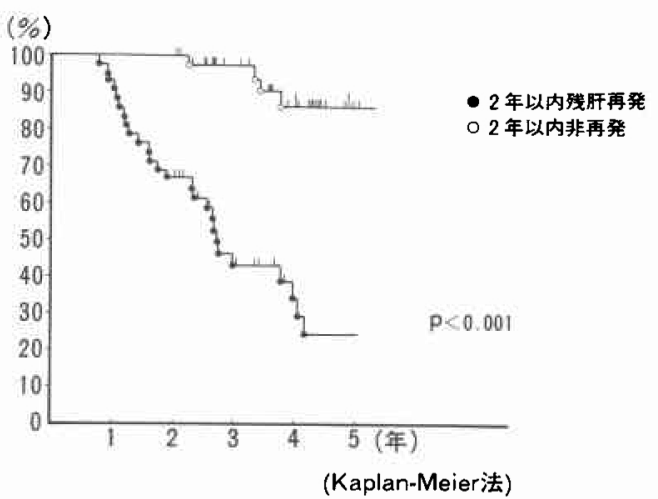

認めた因子は, 術前 AFP 值, 腫晹径, 肉眼分類, Stage, 切除根治度であった. 特に, AFP $20 \mathrm{ng} / \mathrm{ml}$ 以下, 腫瘍 径 $5 \mathrm{~cm}$ 以下, 限局結節型, Stage I, 治瘏切除例で有意 に再発率が低かった. HBs 抗原の有無と 2 年以内残肝 再発とは有意差を認めなかった。TW 因子に関しては TW(十)のほらが再発しやすい傾向にあったが有意差 はなかった，肝切除範囲についても拡大切除の方が再 発率が低い傾向にあったが, 有意差は認めなかった(図 3). 
図 3 術後 2 年以内残肝再発之諸因子の検討
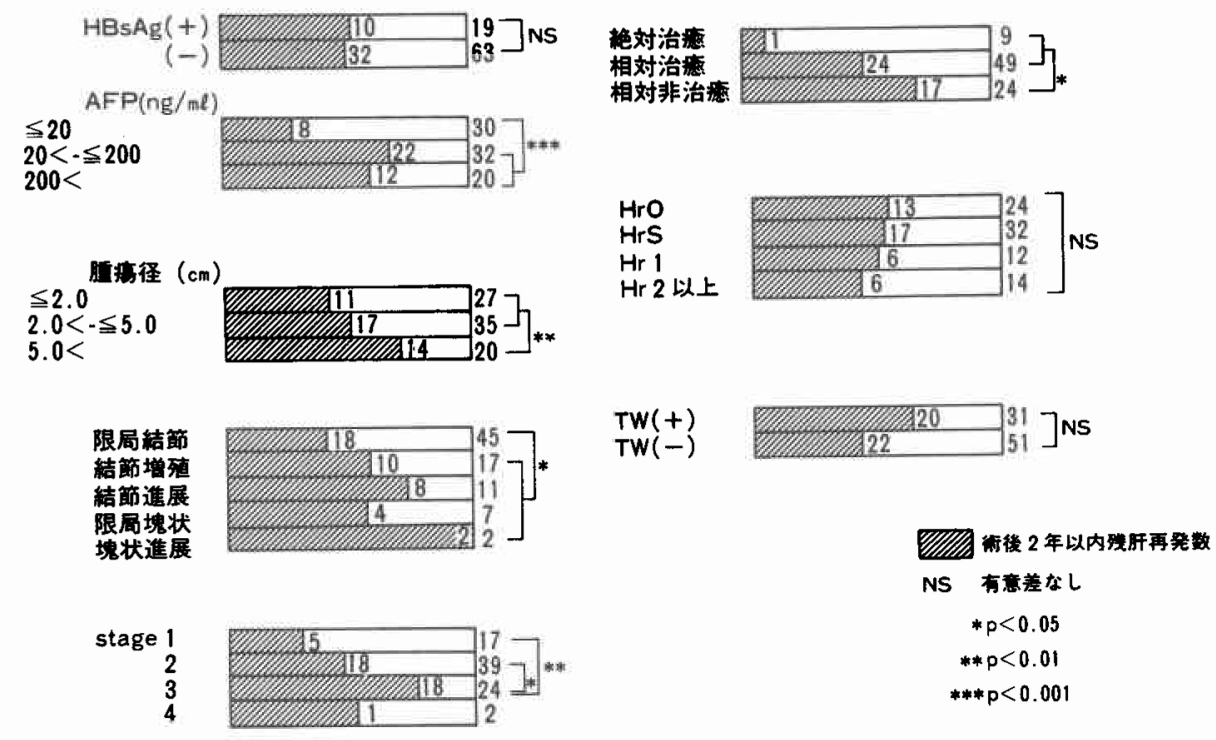

6) 肝内進展様式, 肝硬変の有無と術後 2 年以内残肝 再発

被膜浸潤のある症例 (fc-inf (+)), 門脈侵熟のある 症例 ( $\mathrm{vpl}$ 以上), 肝内転移のある症例 (iml以上), 肝 硬变の症例で再発率が高い傾向にあった。被膜浸潤の ある症例, 肝内転移を有する症例では有意に術後 2 年 以内再発率が高かったが, 被膜形成 (fc) の有無, 門脈 侵襲の有無では有意差を認めなかった。vp2以上の症 例はvpl 以下の症例と比較し非常に高い再発率であっ たが症例数が少ないために有意差は認めなかった（図 4 ).

7) 術前 AFP 值, 腫場径, 肉眼分類, 肝硬变と肝内 進展様式

残肝再発を関連を認めた術前 AFP 值, 腫漡径, 肉眼 分類, 肝硬変の有無と肝細胞癌肝内進展様式との関連 性について検討した。術前 AFP 值が $20 \mathrm{ng} / \mathrm{ml}$ を越兄 る症例では門脈侵嬰, 肝内転移の率が有意に上昇した。 肉眼形態では限局結節型以外の進展型腫蝪で有意汇門 脈侵襲, 肝内転移が多かった。腫瘍径は増大するにつ れ肝内転移が増加する傾向にあり, 肝硬変の有無では 非肝硬変肝で門脈侵襲が多い傾向があった（図 5 ).

肝硬変の有無では腫場径別に検討した。肝硬変例で は $5 \mathrm{~cm}$ 以下で $\mathrm{TW}(+)$ が有意に多く，また，有意差 はないが肝内転移が多かった。非硬変肝では腫瘍径5 $\mathrm{cm}$ 以上で有意に肝内転移が増加した（表 2 ).

8）肝内進展様式間の検討

目 4 肝内進展様式, 肝硬変の有無と術後 2 年以内残 肝再発の検討
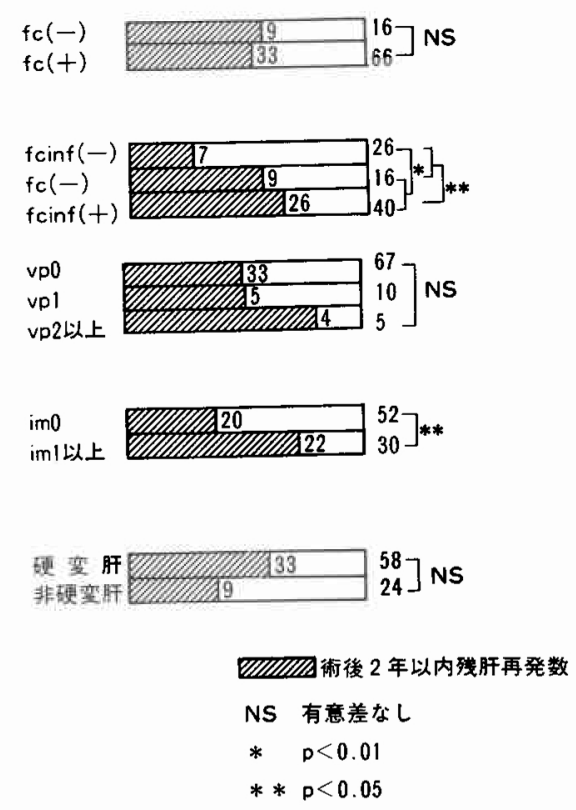

被膜浸潤之門脈侵襲, 門脈侵襲之肝内転移間に有意 の相関を認め, これらの肝内進展様式間には相互に強 い関連性を持つことが示唆された（表 3）.

9）術式, TW 因子, 肝硬变, 腫場径, 肝内進展様式 と 2 年以内残肝再発

数量化II類を用いて計算した。 2 年以内残肝再発と 
図 5 術前 AFP 値, 腫瘍径, 肉眼分類, 肝硬変の有無 と肝内進展因子との関連性の検討

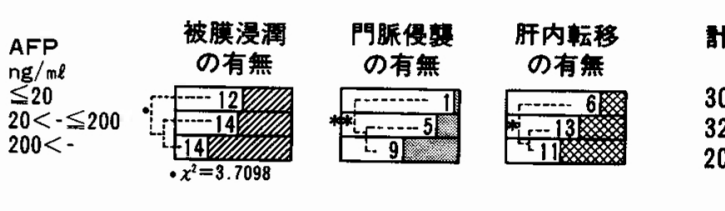

脂瘭膲
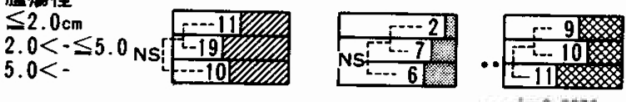

$\cdots x^{i}=2,8876$
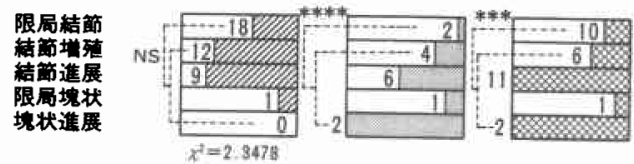

45

17

11

将局地状

$x^{2}=2.347$

肝硬变
掣
有
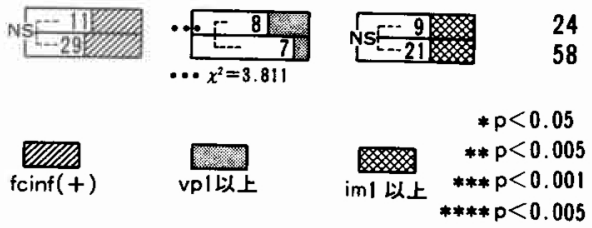

NS 有事童礼

表 2 肝硬変の有無, 腫場径と肝内進展様式, TW 因 子との関連性の検討

\begin{tabular}{|c|c|c|c|c|c|c|c|c|c|c|}
\hline & \multicolumn{4}{|c|}{ 硬变 价 } & & \multicolumn{4}{|c|}{ 非霞 茨 } & \\
\hline y & $f \operatorname{cinf}(+)$ & vp，以上 & im, 以上 & $T W(t)$ & 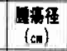 & $f \operatorname{cinf}(+)$ & $v p$ : 以上 & imi以上 & $\mathrm{TW}(+)$ & it \\
\hline 23 & 10 & 2 & 9 & 11 & $\leq 2$ & 1 & 0 & 0 & 0 & 4 \\
\hline 26 & 14 & 4 & 9 & 11 & $2<\sim \leq 5$ & 5 & 3 & 1 & 1 & 9 \\
\hline 9 & 5 & 1 & 3 & 5 & $5<$ & 5 & 5 & 8 & 3 & 11 \\
\hline 58 & 29 & 7 & 21 & 27 & it & 11 & 8 & 9 & 4 & 24 \\
\hline & & & & & & & & $p<0.025$ & & \\
\hline
\end{tabular}

強い関連を認めた項目は肝内転移と被膜漫潤という肝 内進展様式であった（表 4 ）。

10）肝細胞癌肝内進展因子

被膜浸潤，門脈侵襲，肝内転移が相互に強い関連を 持つことから、これらをまとめて肝細胞癌の肝内進展 因子とし，この因子の有無にて検討した，畽場径，肝 硬変の有無と肝内進展因子との関連をみると, 非硬変 肝では腫煌径が増大するつれ肝内進展因子を持つ率が 増加した。しかし, 硬変肝では腫瘍径 $2 \mathrm{~cm}$ 以下の症例
表 3 肝内進展様式間の関連性の検討

\begin{tabular}{|c|c|c|c|c|c|}
\hline & $\begin{array}{l}f \operatorname{cinf}(-) \\
f c(-)\end{array}$ & $f \operatorname{cinf}(t)$ & vpo & vpl以上 & 計 \\
\hline vpo & 39 & \multirow{2}{*}{$\left.\frac{28}{12}\right] *$} & & & 67 \\
\hline vpl以上 & 3 & & & & 15 \\
\hline imo & 31 & 21 & 48 & 47 & 52 \\
\hline iml以上 & 11 & 19 & 19 & $11\rfloor^{*}$ & 30 \\
\hline 計 & 42 & 40 & 67 & 15 & 82 \\
\hline & & & & $\begin{array}{l}0.025 \\
0.005\end{array}$ & \\
\hline
\end{tabular}

表 42 年以内残肝再発に関する項目 と偏相関係数

\begin{tabular}{|c|c|c|c|}
\hline アイテム & カテコリー & スコアー & 俩相閃係数 \\
\hline 简 式 & $\begin{array}{l}\text { 1. } \mathrm{HrO} \\
\text { 2. } \mathrm{HrS} \\
\text { 3. } \mathrm{Hrl} \\
\text { 4. } \mathrm{Hr} 2 \text { 以上 }\end{array}$ & $\begin{array}{c}0.500944 \\
0.0886232 \\
-0.10226 \\
-0.973678\end{array}$ & 0.238719 \\
\hline TW因子 & $\begin{array}{l}\text { 1. } T W(-) \\
\text { 2. } T W(+)\end{array}$ & $\begin{array}{r}-0.258574 \\
0.425396 \\
\end{array}$ & 0.193596 \\
\hline 监要程 & $\begin{array}{l}1 . \leqq 2.0(\mathrm{~cm}) \\
2.2 .0<\sim \leqq 5.0 \\
3.5 .0<\end{array}$ & $\begin{array}{c}-0.427772 \\
0.0212661 \\
0.517825\end{array}$ & 0.203276 \\
\hline 被膜漫秘 & $\begin{array}{l}\text { 1. } f \operatorname{cinf}(-) \\
\text { 2. } f \operatorname{cinf}(+)\end{array}$ & $\begin{array}{c}-0.603313 \\
0.28011\end{array}$ & 0.239348 \\
\hline 門脤侵㦼 & $\begin{array}{l}\text { 1. } v p_{0} \\
\text { 2. } v p_{1} \text { 以上 }\end{array}$ & $\begin{array}{r}0.0504529 \\
-0.225356 \\
\end{array}$ & 0.0581021 \\
\hline 肝内転移 & $\begin{array}{l}\text { 1. } i m_{0} \\
\text { 2. im, 以上 }\end{array}$ & $\begin{array}{r}-0.551115 \\
0.955266\end{array}$ & 0.380724 \\
\hline 非福肝 & $\begin{array}{l}\text { 1. 硬変肝 } \\
\text { 2. 非硬变肝 }\end{array}$ & \begin{tabular}{|c|}
-0.11684 \\
0.483328
\end{tabular} & 0.0376098 \\
\hline
\end{tabular}

でも半数以上に肝内進展因子を認めている（図 6).

11）肝細胞癌肝内進展因子の有無酒残肝再発率 肝内進展因子の有無により 2 年以内残肝再発率を $x^{2}$ 検定にて計算した。ささらに Kaplan-Meier 法により 非再発生存率を計算し，一般化 Wilcoxon 検定を施行 した。これらにより 2 年以内残肝再発，および全体の 再発率は肝内進展因子を有する症例が有意伿かった (図 7,8). 
図 6 肝硬変の有無, 腫瘍径と肝内進展因子との関連 性の検討

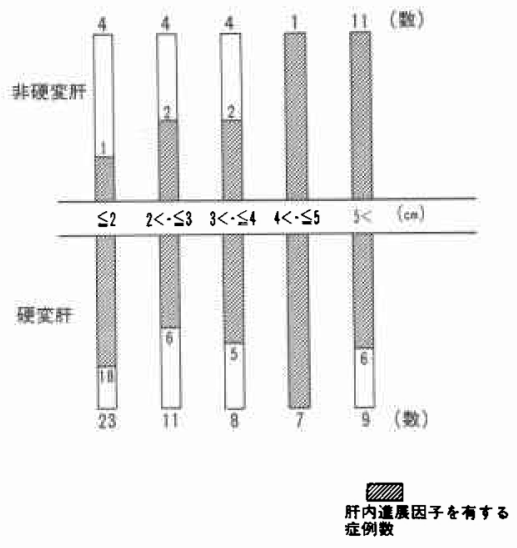

図 7 肝内進展因子の有無による術後 2 年以内残肝再 発率の比較検討

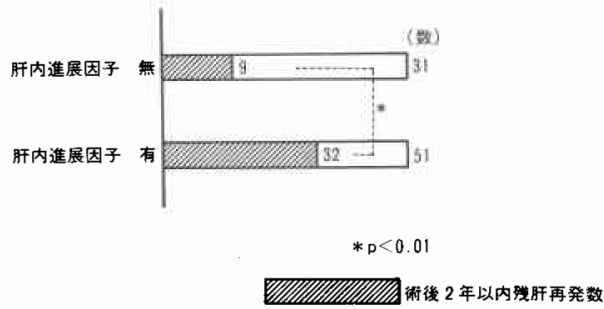

図 8 肝内進展因子の有無による非再発生存曲線

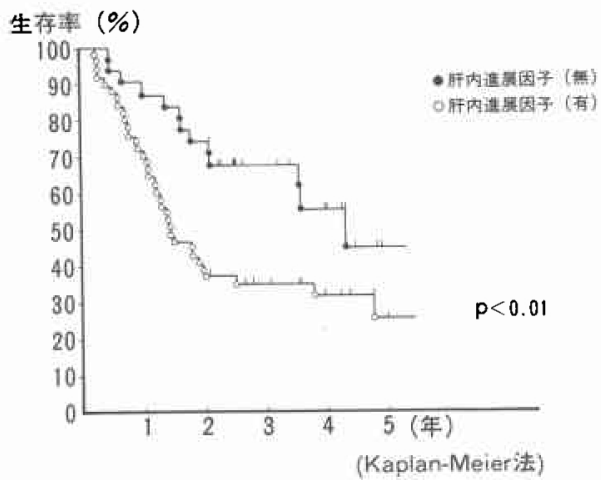

考 察

1. 再発

肝細胞癌切除後の再発の場合, これがいわゆる再発 であるのか，あるいは異時性発癌であるのか臨床的に も, 病理組織学的にす明確に判断できないのが現状で ある゙、。かし，いずれにしてむ臨床的には切除後に再 び肝細胞癌が出現することが現実であり，これらを広
義の意味の再発としてなんら差し支えはないと考えて いる．本研究においても治癒切除または相対的非治癒 切除例を対象とし，その術後に肝細胞癌が再び出現し た場合を再発として検討した。

2. 残肝再発の時期

肝細胞癌の残肝再発の時期は残肝再発例の $80 \%$ が 2 年以内であるということは特徵的である．他の報告も 同様である45)。これは，再発の大部分は主腫瘍からの 転移病巣である可能性を暗に示唆していると考兄られ る。また術後 2 年以内再発例は有意に生存率が低く， 再発までの時期は癌悪性度を反映しているるのと考え られた。そこで， 2 年といら期間を癌の doubling time (以下 DT)から考えてみた . 腫瘍径 $1 \mathrm{~mm}$ の腫瘍が術 後 2 年間で臨床的に診断可能な $1 \mathrm{~cm}$ になると仮定す ると, DTは約 2 か月となる。これは小渋らかが主結節 $2 \mathrm{~cm}$ の肝細胞癌で計算した DT（11.23か月）と比較す ると非常に短かく, 肝切除後の転移病巣での腫瘍発育 速度が非常に早い可能性が示唆された8)。また，2年以 降再発の症例は非常に slow growing であるのか, あ るいは異時性多中心性発癌であるのか, いずれにして 女単発, 小病変として発見されて扣り悪性度の低い腫 瘍と考えられる。このことから，2 年以内再発の可能 性を予測することは，肝細胞癌の集学的治療に非常に 重要であると考えている。

3. 肝細胞癌肝内進展様式と残肝再発の病態 おの打のの肝内進展様式と残肝再発について考察し た。

最初に門脈侵襲について述べるが，本研究では門脈 侵襲と再発之は明かな関連性は認めなかった。この原 因として，術前に明かな門脈腫煌栓と診断されるよう な症例は術前 TAE 療法を施行したり，あるいは絶対 非治癒切除となって対象からはずれたことを考慮しな ければならない。また，病理組織学的に門脈侵襲を見 いだすのは非常に詳細な検索が必要であり，実際に診 断して得ている症例は，ごく少数例のみである可能性 がある点も大切である9).ところで, 症例数が少なく有 意差はなかったが, vp2の症例は肝内転移が多く，2 年 以内残肝再発も高率であった。これらから，門脈侵襲 を確実に診断し得れば，さらに再発の予測の確率が高 くなると思われた。

次に, 被膜浸潤について考察する.岡部 ${ }^{10)}$ が癌結節の 被膜について詳細に検討を加えているが，そのなかで 癌被膜内の門脈枝が癌結節の輸出血管としての役割を 果していることを示している. 実際の切除標本の病理 
組織学的な検討に括いても，被膜浸潤の大部分は被膜 内の偏平な血管内に腫瘍が浸潤している。このことか らも, 被膜浸潤は非常に門脈侵襲と関連があり, 被膜 浸潤のある症例は門脈侵襲があると考文対処する必要 があると考えている．また，今後，被膜浸潤を被膜内 血管侵襲と被膜内間質浸潤に分けて再検討する必要が あると考壳た。

また, 肝内転移の有無が再発との関連性が一番強い 因子であったが，これは転移巣が門脈侵襲，被膜浸潤 と比較し臨床的にも確実に所見を取りやすいといら可 能性がある. 逆に, 顕微鏡的な被膜浸潤や門脈侵襲を 術前に診断する手だてを持ち合わせていない現在, こ とさら肝内転移巣を確実に拾い上げる努力が必要であ る. 癌結節は $1 \mathrm{~cm}$ 以下となると術前の画像診断にて質 的診断が不明確となるが11), 肉眼的にも診断可能であ る3 5mm 前後の腫瘍結節を確実に診断する方法の確 立が望をれる，そのなかで，高崎らが報告したアンジ オェコー-法 ${ }^{12)}$ は $1 \mathrm{~cm}$ 以内の癌結節を診断する方法と して今後注目されると思われる。

今回の検討で重要なことは, これらの肝内進展様式 が相互に強い関連を認めていることと, 腫煬の肝内進 展の有無で残肝再発率に有意差を認めたことである. 再発, 予後を検討する場合, これらの肝内進展を考虑 せずに検討すると, 腫瘍径や肝硬変の有無だけで結論 をだしてしまら危惧がある。腫焬径が再発，あるいは 予後に関連しているという報告がある1314)が，これは 腫煌径が大きくなるにつれて肝内進展因子を持つ症例 が增加するということである。また，畽場径のみなら ず, 術前 AFP 值 $20 \mathrm{ng} / \mathrm{ml}$ 以下, 限局結節型の腫場は肝 内進展因子を持つ確率が少ないために, 残肝再発率が 低くなったと考光ている。

肝内進展因子を認めないにもかかわらず術後再発し た症例は 15 例であった。 つち 9 例 $(60 \%)$ は術後 2 年 以内であり (図 7)，他の 6 例は 2 年以降であった。こ の15例の検討では, 14例が高度肝硬変例で, 腫場径は $2 \mathrm{~cm}$ 以下 6 例, $2 \sim 5 \mathrm{~cm} 6$ 例, $5 \mathrm{~cm}$ を越える症例は 3 例

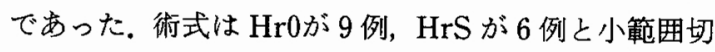
除で，TW因子は10例で陽性であった。このような症 例では肝内転移巣の診断拉よび肝切除範囲が不十分で あった可能性もあるが，このなかに多中心性発癌症例 が含まれる可能性があり，さらに検討が必要である。

4. 非肝癌について

森は昭和 31 年“へパトームの転移に関する研究”15)の なかで腫瘍の転移を考察する場合には腫瘍の置かれて
いる周囲環境状態を考慮する必要のあることを強調し ている. 本研究でも, 肝硬変例で再発率の高い傾向が あった。これは再生結節との鑑別診断の困難さや切除 範用の制限などを考慮しなくてはならないが，さらに 畽湯径が小さな症例でも肝硬変例では半数以上に肝内 進展因子を認めていることに注目しなくてはならな い. その肝内進展因子の大部分は, 被膜浸潤と肝内転 移であった. 硬变肝併存の有無により被膜形成に相違 がみられることや10), 癌結節周囲の循環動態に異常が みられることが, 畽瘍の肝内進展になんらかの影響を 及ぼしている可能性も考兄られた。肝硬变例では, 畽 瘍径が小さとと肝内進展因子を持つ可能性が高く， とくに肝内転移に関し十分な術前, 術中の検索が必要 である。

\section{結 論}

観察術後期間 8 年10か月から 9 か月までの肝細胞癌 82 例の切除標本について肝細胞癌の進展様式を検索 し, 残肝再発との関連性について検討し以下の結論を 得た。

1）肝細胞癌切除 82 例中 51 例 $(62 \%)$ に残肝再発をき たし，その再発の時期は 42 例 $(82 \%)$ が 2 年以内であっ た。

2) 術後 2 年以内残肝再発例は 2 年以内非再発例之 比較し有意に生存率が低かった $(\mathrm{p}<0.001$, 一般化 Wilcoxon 検定).

3）術前 AFP が $20 \mathrm{ng} / \mathrm{ml}$ 以下, 腫瘍径 $5 \mathrm{~cm}$ 以下, 限 局結節型, 肉眼進行度 Stage I, 治癒切除の症例で有意 に残肝 2 年以内再発率が低かったが, HBs 抗原の有 無, 術式, TW 因子の有無と残肝 2 年以内再発とに有 意な関連は認めなかった。

4) 肝内進展様式の検討では被膜漫潤のない症例 $\left(\mathrm{p}<0.01, \chi^{2}\right.$ 検定 $)$, 肝内転移のない症例 $(\mathrm{p}<0.05$, $x^{2}$ 検定) で残肝 2 年以内再発率が有意に低かったが, 門脈侵襲の程度では明かな有意差は認めなかった。

5） 2 年以内残肝再発にかかわる要因の重みについ て数量化第IIを用いて検討すると, 肝内転移, 被膜浸 潤の有無などの肝内進展の因子の重みが大きかった。

6) 被膜浸潤, 門脈侵襲, 肝内転移は相互に有意な相 関を認めた。そこでこれらの因子をまをめて肝細胞癌 肝内進展因子とすると，この因子の有無にて残肝再発 率に有意差を認めた（ $\mathrm{p}<0.01$, 一般化 Wilcoxon 検 定).

稿を終えるにあたり, 御指導, 御校閲を賜りました羽生富 士夫教授に深甚なる感謝の意を表します。研究の機会を頂 
きました小林誠一郎教授，鈴木博孝教授に心から御礼申し 上げをす。をた直接御指遒, 御教示を頂きました高崎健助 教授に心からの感謝を捧げます.さらに, 病理組織学的検索 を直接御指導頂末した東京都立衛生研究所の中野雅行先 生, 肝外科グループの諸先生, 消化器病理検査室の諸兄に心 から御礼申し上げます。

な技本論文の要旨は, 第 30,31 回日本消化器外科学会総会 にて発表した。

\section{文献}

1）日本肝癌研究会編：臨床・病理. 原発性肝癌取扱い 規約 (第 2 版). 金原出版, 東京, 1987

2) 高崎 健: 肝硬变併存肝癌の切除術式を選択基準 一安全性, 根治性を考虑に入れた切除範囲の調節 とそれに必要な手術手技の工夫一。日消外会誌 $19: 1881-1889,1986$

3）奥平雅彦，佐々木憲一：原発性肝癌は多中心性発 生加。肝・胆・膵 $5: 933-937,1982$

4) 岡本英三, 山中若樹, 加藤年啓注か：肝切除術後再 発肝癌。肝・胆・膵 $15: 475-480,1987$

5）高安賢一, 村松幸男, 森山紀之潘か：小型肝細胞癌 97例の術後残肝再発に関する臨床放射線的検討。 日消病会誌 $84: 1424-1432,1987$

6) 草間 悟：癌の時間学. 草間 悟編. 臨床腫煌学. 南江堂, 東京, 1982, p129-156
7）小沿陽一, 大藤正雄, 江原正明伍か：長期自然経過 観察にもとずく，小肝細胞癌の発育速度と進展経 過, 及びこれらに関与する因子についての研究. 日 消病会誌 $83: 800-811,1986$

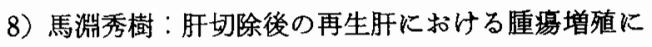
関する研究。日消外会誌 $18: 765-772 ， 1985$

9）神代正道：小らな肝癌の病理形態学的特徽。病理 と臨 $6: 278-283,1988$

10) 岡部正之: 原発性肝癌の病理形態学的研究. 肝細 胞癌に㔚ける癌結節の被膜並びに隔壁の形成機転 について。肝缄 $20: 144-155,1979$

11）高安賢一: 肝の微小癌 B. 肝徽小病変の画像診断. 病理と臨 5(臨增)：180-192, 1987

12）斉藤明子, 高崎 健, 中川昌之ほか：肝腫县の診断 飞打ける脈管内炭酸がス注入アンジオ・エコー法 の応用. 肝・胆・萃 $15: 1129-1132,1987$

13）泉 良平, 小林弘信, 谷屋隆雄住か：肝細胞癌再発 例の检討. 日消外会誌 $21: 831-835,1988$

14）佐野秀一, 中西昌美, 渡辺修一ほか：原発性肝癌 （腫瑒径 $5 \mathrm{~cm}$ 以下)の診断および治療上の問題点。日 消外会誌 $18: 773-778,1985$

15）森亘：へパトームの転移に関する研究一特に 肝硬変症との関係に就いて一, 日病理会誌 45 ： 224-236, 1956 